\title{
Battery energy storage systems for the electricity grid: UK research facilities
}

Link to publication record in Manchester Research Explorer

\section{Citation for published version (APA):}

Feehally, T., Forsyth, A., Todd, R., Foster, M. P., Gladwin, D., Stone, D. A., \& Strickland, D. (2016). Battery energy storage systems for the electricity grid: UK research facilities. 1-6. Paper presented at IET Power Electronics, Machines and Drives, Glasgow, United Kingdom.

\section{Citing this paper}

Please note that where the full-text provided on Manchester Research Explorer is the Author Accepted Manuscript or Proof version this may differ from the final Published version. If citing, it is advised that you check and use the publisher's definitive version.

\section{General rights}

Copyright and moral rights for the publications made accessible in the Research Explorer are retained by the authors and/or other copyright owners and it is a condition of accessing publications that users recognise and abide by the legal requirements associated with these rights.

\section{Takedown policy}

If you believe that this document breaches copyright please refer to the University of Manchester's Takedown Procedures [http://man.ac.uk/04Y6Bo] or contact uml.scholarlycommunications@manchester.ac.uk providing relevant details, so we can investigate your claim.

\section{OPEN ACCESS}


This paper was published at the IET Power Electronics, Machines and Drives (PEMD) Conference in April 2016, doi 10.1049/cp.2016.0257.

T Feehally, A J Forsyth, R Todd, M P Foster, D Gladwin, D A Stone, D Strickland, "Battery energy storage systems for the electricity grid: UK research facilities," 8th IET International Conference on Power Electronics, Machines and Drives (PEMD), April 2016, doi: 10.1049/cp.2016.0257

(C) 2016 IET. Personal use of this material is permitted. Permission from the IET must be obtained for all other uses, in any current or future media, including reprinting/republishing this material for advertising or promotional purposes, creating new collective works, for resale or redistribution to servers or lists, or reuse of any copyrighted component of this work in other works. 


\title{
Battery energy storage systems for the electricity grid: UK research facilities
}

\author{
T Feehally*, A J Forsyth*, R Todd ${ }^{*}$, M P Foster ${ }^{\dagger}$, D Gladwin ${ }^{\dagger}$, D A Stone ${ }^{\dagger}$, D Strickland ${ }^{\sharp}$ \\ *School of Electrical and Electronic Engineering, The University of Manchester, Manchester, UK \\ ${ }^{+}$Department of Electronic and Electrical Enerineering, The University of Sheffield, Sheffield, UK \\ ${ }^{\#}$ Engineering \& Applied Science, Aston University, Birmingham, UK \\ Email: tom.feehally@manchester.ac.uk, m.p.foster@sheffield.ac.uk
}

Keywords: grid-scale, battery, energy storage, hardware.

\begin{abstract}
Grid-connected battery energy storage systems with fast acting control are a key technology for improving power network stability and increasing the penetration of renewable generation. This paper describes two battery energy storage research facilities connected to the UK electricity grid. Their performance is detailed, along with hardware results, and a number of grid support services are demonstrated, again with results presented. The facility operated by The University of Manchester is rated at $236 \mathrm{kVA}, 180 \mathrm{kWh}$, and connected to the $400 \mathrm{~V}$ campus power network, The University of Sheffield operates a $2 \mathrm{MVA}, 1 \mathrm{MWh}$ facility connected to an $11 \mathrm{kV}$ distribution network.
\end{abstract}

\section{Introduction}

Power balance in the electricity grid has traditionally been achieved by ramping generation to match demand [1]. This is detrimental to both plant efficiency and life [2], and is insufficient when high levels of non-controllable 'renewable' generation exist. Grid connected energy storage overcomes these limitations by providing a power buffer, which decouples the load from the generation capacity [3], to maximise efficiency and optimise the carbon intensity of the power network.

Battery energy storage systems (BESSs) are becoming economically viable for grid connected energy storage [4]. Electrochemical energy storage in battery modules can be both modular and scalable, while offering high round trip efficiency, long cycle life, and with low maintenance requirements [2]. BESSs can perform a wide range of grid support services which improve network efficiency and stability [5], thus increasing profitability [4]. Crucially battery systems are also able to provide the fast response rate required to achieve many of the high value benefits from grid connected energy storage [6].

BESSs with a fast control response are a key technology in facilitating the increased uptake of renewable generation systems [1]. Renewably generated electrical energy can be stored when its output exceeds network capacity and supplied when load demand is high [7] thus ensuring that dispatch commitments are met. For example research, [8], has suggested that energy storage with a 10 minute capacity can allow $10 \%$ more wind energy to be absorbed without network reinforcement. Furthermore, an inability to store energy contributes to short term volatility in the energy market [9] which in turn may deter investment, particularly in renewable generation sources.

The modern power network requires energy storage in order to improve its efficiency and use of renewable generation, however, BESSs are costly and so the local power system operator may incentivise their installation by regulation, direct finance, or indirectly by paying for the services they provide. To really drive the installation of network storage capacity the BESS must offer a good financial return to investors, with income outstripping the devaluing, or aging, of the main asset, the battery. The business case for energy storage requires value to be accrued from multiple grid services [10]. Therefore the challenge is to optimise the BESS control to provide multiple services while minimising battery aging.

\subsection{Existing battery energy storage systems}

This section provides an overview of BESS installations throughout the world detailed in academic literature, with a particular focus on UK-based systems with lithium batteries. Initial findings have been published from a $200 \mathrm{~kW}, 200 \mathrm{kWh}$ BESS connected to the $11 \mathrm{kV}$ distribution network near Great Yarmouth, UK [11]. However, results show a response time frame of minutes, not fully utilising the capability of the technology. Table 1 lists lithium-based BESS and their usage.

Table 1: Installed grid-connected lithium-ion BESS

\begin{tabular}{|l|l|l|}
\hline Rating & Location & Usage / comment \\
\hline $10 \mathrm{MW}$, & Feldheim, & Grid load and frequency support \\
$10.8 \mathrm{MWh}$ & Germany & \\
\hline $6 \mathrm{MW}$, & Leighton & For upgrade deferral, peak shaving, \\
$10 \mathrm{MWh}$ & Buzzard, UK & arbitrage [12] \\
\hline $200 \mathrm{~kW}$, & Great & For research, 11kV connection, [11] \\
$200 \mathrm{kWh}$ & Yarmouth, UK & \\
\hline $250 \mathrm{~kW}$, & Quebec, & Lithium-ion, for research [13] \\
$100 \mathrm{kWh}$ & Canada & \\
\hline
\end{tabular}


Globally there are a large number of BESSs in commercial operation, with the majority of them used to smooth the output from renewable generation. BESS technology is most commonly used in Japan [14] [15] [6] and the USA [16] [17] [18] [6]. The number of commercial installations demonstrates a positive outlook on the economic viability of BESSs.

This paper considers fast acting control of BESS with practical results from active hardware. The two hardware systems are installed for research purposes meaning that full control of their operation is afforded to academic use.

\section{Grid services offered by energy storage}

Energy storage is typically installed with the aim of providing a single function to the grid or local user; this ensures a straightforward economic assessment for installation and operation. Alongside these primary services, the storage can also be tasked to provide ancillary services for the grid, which may be paid, but the exact mechanism varies according to the local power system operator.

Primary services include: Upgrade deferral for transmission and distribution systems by easing network congestion [16], this is particularly required where high levels of renewable generation exist [19]. Capacity firming by providing a power buffer to ensure economic despatch [20], allowing generators to avoid financial penalties on despatch bids [21]. Price arbitrage to take advantage of price difference in the free energy market [18], backup power for emergency or selective islanding [10], and the time shifting of energy which may be used for peak shaving.

Ancillary services contribute to the stability and health of the overall power network, and are best characterised according to the time scale on which they operate [18]. Primary and ancillary services provided by BESS are shown with their time scale and approximate value in Figure 1.

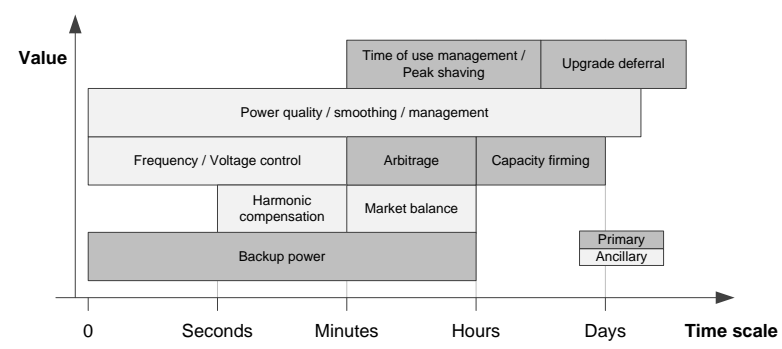

Figure 1: BESS grid services with time scale

To ensure stability, the power network requires frequency control and power quality support at a rapid ramp rate, this is often referred to as spinning reserve [21], and also acts to stabilise the energy market [18]. Power management may take place over a broad time scale to support the network in relation to specific assets and conditions, and as such has a high value. Frequency regulation and power smoothing are also required over a longer time frame [18]. Harmonic compensation and voltage control, by power factor correction are also achievable. Power flow management may be used to correct for short duration faults, to longer term weather and seasonal variations in load and generation [10].

\section{System descriptions and performance}

This section provides detailed descriptions of both the hardware and control schemes for the BESSs at the University of Manchester and The University of Sheffield. Performance data is also provided including: round-trip efficiency, ramp rate, and control bandwidth.

\subsection{University of Manchester}

The University of Manchester has recently commissioned a $236 \mathrm{kVA}, 180 \mathrm{kWh}$, BESS which is connected to the $400 \mathrm{~V}$ campus power network within the Manchester city centre. The energy store consists of four banks of fourteen series connected 48V lithium-ion polymer battery UPB4860 modules, supplied by LG Chem. Each of the banks has their own Battery Management System (BMS) which monitors the cell voltage and temperature, and reports SOC and SOH. The battery banks are arranged in two pairs each connected to a $118 \mathrm{kVA}$ inverter; the inverters are paralleled on the AC side. The power hardware is designed and built by Siemens and marketed under the name SieStorage. The electrical power connections as well as the control structure are shown in Figure 2; a photograph of the facility is shown in Figure 4.

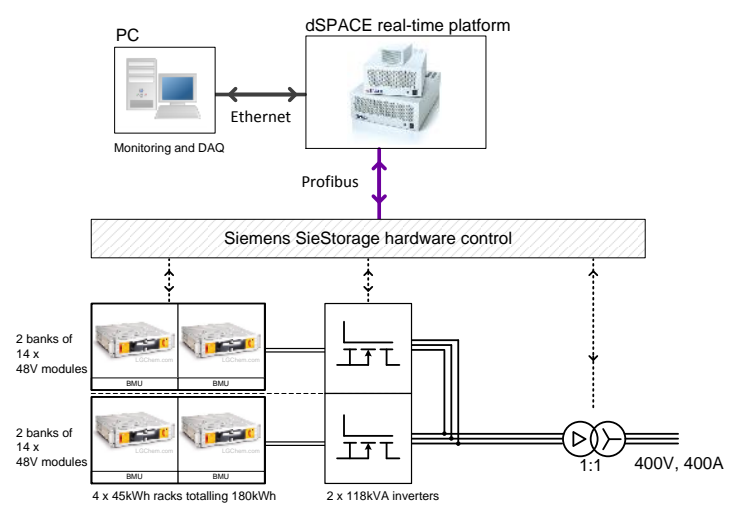

Figure 2: Schematic-180kWh BESS with real-time controller

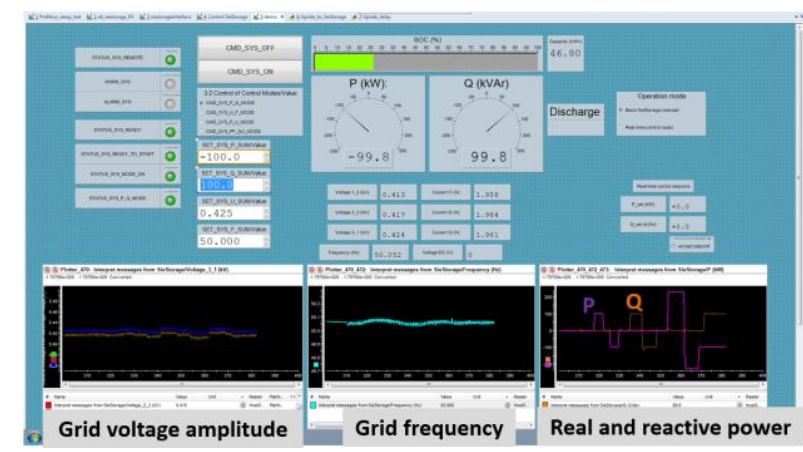

Figure 3: Real-time controller HMI screenshot 


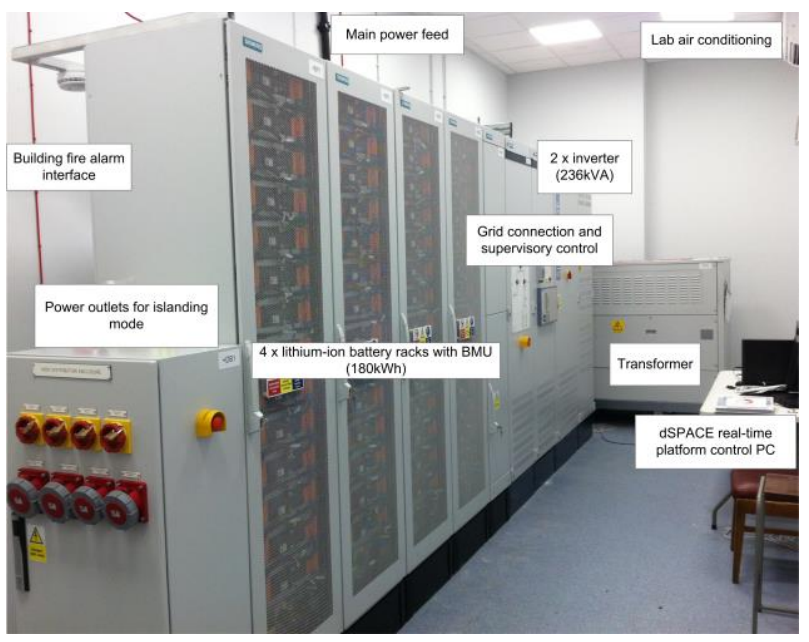

Figure 4: Photograph-BESS facility

The SieStorage system has a dedicated hardware controller which monitors signals from the battery racks, inverters, transformer and network connection, and commands the inverter set-points. The hardware control ensures the safe operation of the BESS and can perform several operational and service functions. A bespoke control interface, using a dSPACE real-time controller has been developed, which can access all the measurements made by the hardware controller and controls the power flow delivered by the inverters. The BESS with real-time control has a control bandwidth of approximately $0.5 \mathrm{~Hz}$. A HMI, shown in Figure 3, allows realtime control of the BESS and can be used to implement control algorithms, and record measurements over long durations.

\section{Performance data (University of Manchester)}

The rapid response of the BESS to a full power $(230 \mathrm{~kW})$ discharge to a full power $(230 \mathrm{~kW})$ charge is shown in Figure 5 .

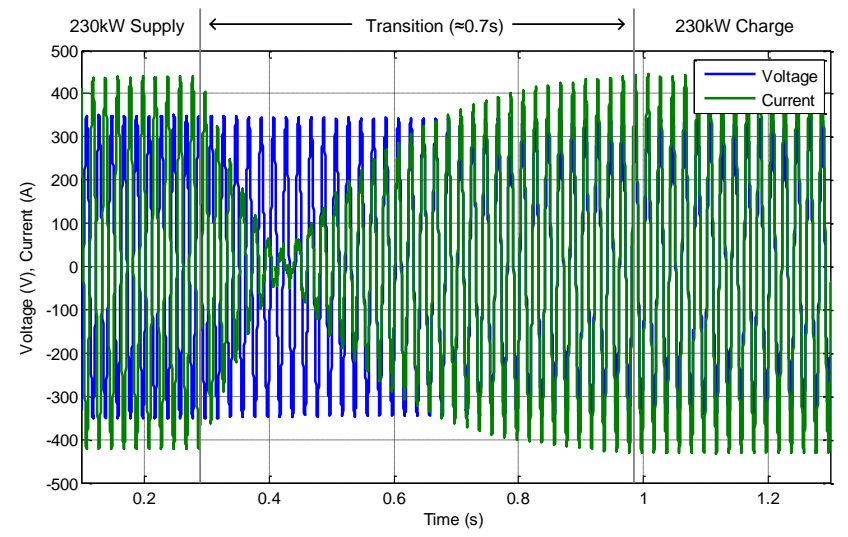

Figure 5: Voltage and current for transition from supply to charge at rated power

Initially the phase voltage and current are $180^{\circ}$ out of phase representing unity power factor operation while the battery is being discharged. The reversal of the power output is requested at approximately $0.3 \mathrm{~s}$ in Figure 5. In response to this change in power set-point, the RMS current falls rapidly to zero in a little over $0.1 \mathrm{~s}$, before being ramped up over approximately 0.6 s until the current equals the nominal value and is in phase with the voltage; during this region the battery is being charged. The full transition takes approximately $0.7 \mathrm{~s}$ and represents a power swing of nearly 0.5MW. Although the fast dynamics of the inverters offer the potential for a more rapid transition the ramp rate of the current is limited in order to protect the battery. A low harmonic distortion in the waveforms can also be observed, which has a THD of $2.8 \%$ at nominal power, which is comparable to the measured THD of $3.0 \%$ with the BESS power breakers open.

The round trip efficiency of the BESS is calculated from measurements of SOC and power when the battery is fully charged and discharged at rated power; such waveforms are shown in Figure 6.

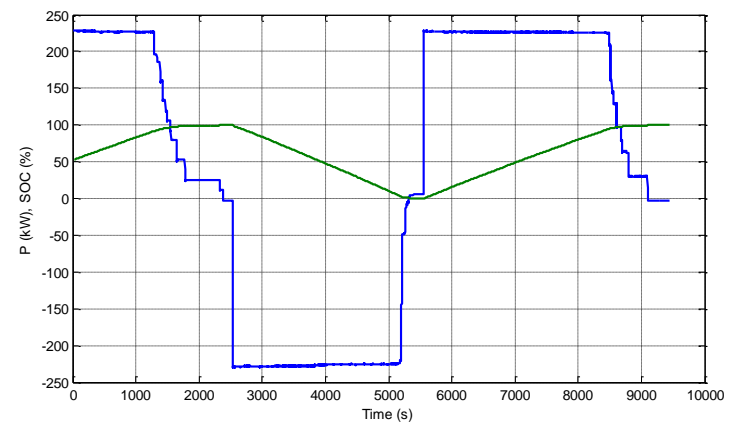

Figure 6: $\mathrm{P}$ and SOC for a full charge and discharge cycle

The initial SOC in Figure 6 is just above $50 \%$ and rises to full charge as rated power is applied. When SOC reaches $100 \%$ the power is reversed until SOC falls to $0 \%$ before again charging to $100 \%$. SOC rises and falls linearly, but as it approaches $0 \%$ or $100 \%$ the hardware controller reduces the power level to limit battery current.

A full charge of the battery, at rated power, uses $194.4 \mathrm{kWh}$, while the full discharge of the battery, at rated power, delivers $169.9 \mathrm{kWh}$. This represents a round trip efficiency of $86.6 \%$, this figure include the power consumption of the control platforms, the BMS system, self-discharge of the batteries, and transformer losses but excludes air conditioning.

\subsection{The University of Sheffield}

The University of Sheffield (TUoS) has built a bespoke 2MVA, 1MWh BESS based on a Toshiba Lithium Titanate battery and a 2MVA ABB inverter. The interface and communication between the two parts of the system is done by a bespoke control system built by the University of Sheffield. An overview schematic of the system is shown in Figure 7. 


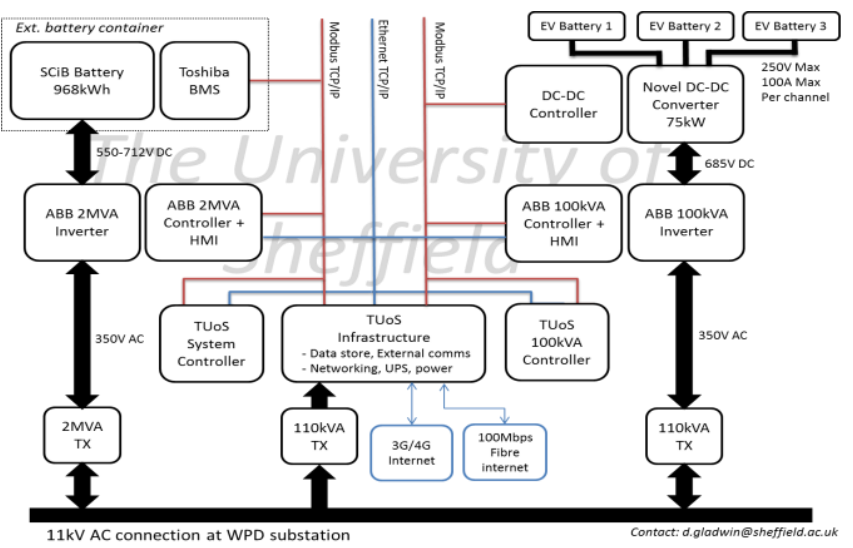

Figure 7: TUoS BESS schematic

In addition to the BESS, a flexible DC / DC and 100kVA inverter based system is installed for interfacing 'second life' EV batteries to the utility supply for grid support applications. The systems are grid connected to the $11 \mathrm{kV}$ utility supply at the WPD Willenhall substation in the West Midlands. To facilitate operation, the whole system can be controlled remotely over a dedicated VPN connection, over 'fibre' or a $3 \mathrm{G}$ network. Data from the system is available via an SQL database, updated on a 1s timescale, and can allow access to voltage, current and temperature of any of the $>21,000$ cells in the system. The bespoke nature of the system allows flexible control and rapid response from the hardware.

The TUoS system is capable of power transients from $2 \mathrm{MW}$ charging to $2 \mathrm{MW}$ discharging within 2 cycles of the utility supply. An example of the transient capability is shown in Figure 8 , which shows the 3 phase currents on the $350 \mathrm{~V}$ side of the $350: 11 \mathrm{kV}$ transformer, when a discharge transient from 0 to $2 \mathrm{MW}$ is requested from the system.

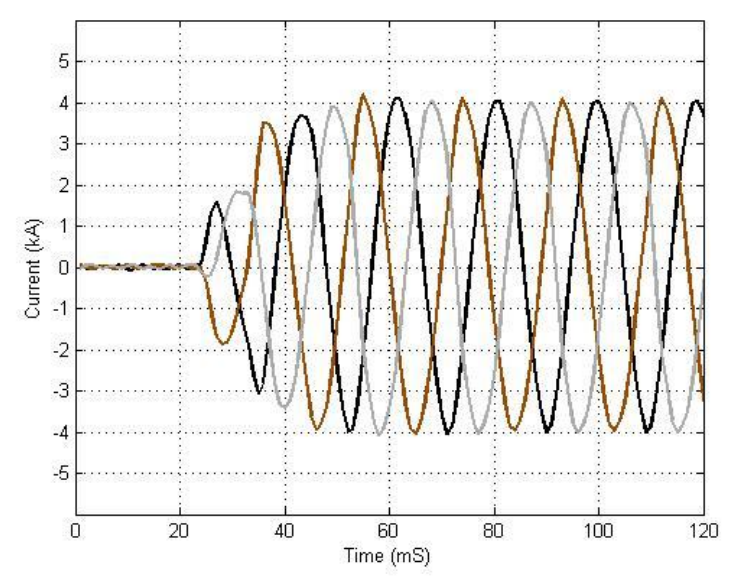

Figure 8: TUoS Output phase current transient

Both the BESS and the second life systems are capable of being fully controlled remotely, or switched to local control where the inbuilt controller can perform programmed tasks, for example frequency response following the National Grid EFR tender regime, as shown in Figure 9.

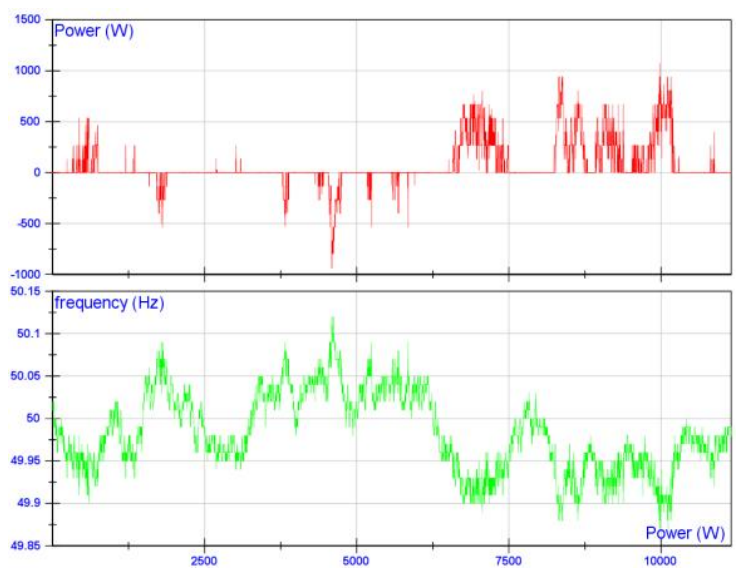

Figure 9: EFR frequency response, frequency (green) and output power (red) against time (seconds)

\section{Demonstration of grid support services}

The majority of grid services are implemented by injecting or absorbing real $(\mathrm{P})$ or reactive power $(\mathrm{Q})$, in response to grid conditions. Figure 10 shows the output real and reactive power in the bottom plot, together with the measured grid frequency and average line voltage over a 3 minute period for The University of Manchester BESS. At 43s the BESS is charged at $227 \mathrm{~kW}$ for $15 \mathrm{~s}$, before being returned to zero, at $74 \mathrm{~s}$ it is discharged at $-227 \mathrm{~kW}$ for $17 \mathrm{~s}$ before being returned to zero. At $110 \mathrm{~s}, 100 \mathrm{kVA}$ is absorbed for $16 \mathrm{~s}$ and at $143 \mathrm{~s}$, $100 \mathrm{kVA}$ is injected for $18 \mathrm{~s}$, at all other times Q is zero.
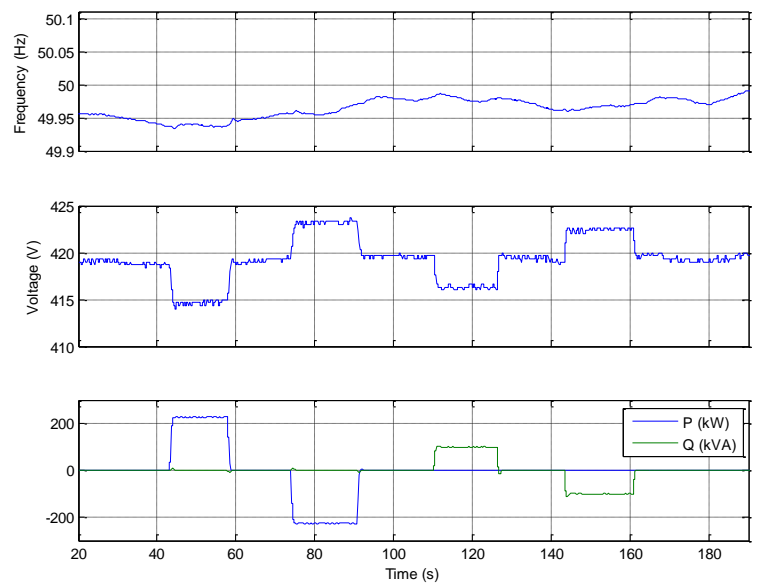

Figure 10: Influence of P and Q on LV power network

Grid frequency in Figure 10 varies between approximately $49.95 \mathrm{~Hz}$ and $50 \mathrm{~Hz}$ within the normal expected range. Average grid line voltage is approximately $419 \mathrm{~V}$.

Neither $\mathrm{P}$ or $\mathrm{Q}$ have an impact on grid frequency (beyond transient measurement noise) as it is too stiff. The real power decreases the grid voltage by $4.5 \mathrm{~V}$ and increases it by $5.2 \mathrm{~V}$, while the reactive power decreases voltage by $2.7 \mathrm{~V}$ and increases it by $3.4 \mathrm{~V}$. This demonstrates that the BESS has sufficient rating to influence the local power network and can support it with both $\mathrm{P}$ and $\mathrm{Q}$. 


\subsection{Frequency and voltage control}

Real and reactive power support for the local power network is achieved using the simplified control scheme shown in Figure 11. All of the set-points, minimum and maximum values shown in Figure 11 can be modified to adjust the level of grid support or best utilise available storage capacity. When frequency or voltage exceeds the deadband zones $\left(\mathrm{F}_{\min }\right.$ to $\mathrm{F}_{\max }$ and $\mathrm{V}_{\min }$ to $\mathrm{V}_{\max }$ ) power is delivered/absorbed according to the set-point gains.

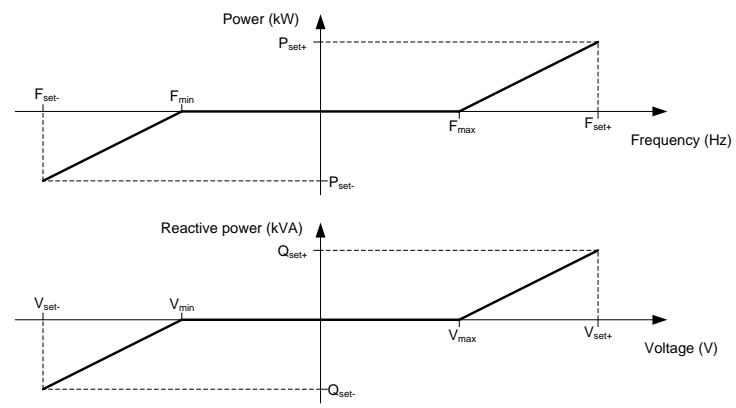

Figure 11: $\mathrm{P}($ frequency) and $\mathrm{Q}($ voltage) profiles

During prolonged operation the frequency, voltage, $\mathrm{P}$ and $\mathrm{Q}$, and SOC are recorded, data from a two hour period is shown in Figure 12 from The University of Manchester BESS. The deadbands and gains tested are $F_{\min }=49.99 \mathrm{~Hz}, F_{\max }=50.01 \mathrm{~Hz}$, $\mathrm{V}_{\min }=420 \mathrm{~V}, \quad \mathrm{~V}_{\max }=430 \mathrm{~V}, \quad \mathrm{P}_{\text {set }} / \mathrm{F}_{\mathrm{set}}= \pm 200 \mathrm{~kW} / \mathrm{Hz}$ $\mathrm{Q}_{\text {set. }} / \mathrm{V}_{\text {set }}=+12 \mathrm{kVA} / \mathrm{V},-3.4 \mathrm{kVA} / \mathrm{V}$.
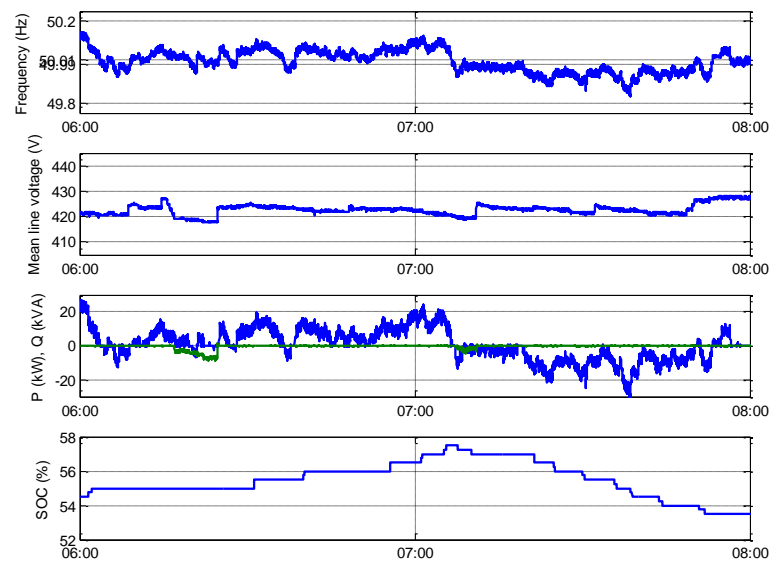

Figure 12: Measurements of $\mathrm{P}(\mathrm{f}) / \mathrm{Q}(\mathrm{V})$ support 13.01.2015

$\mathrm{P}$ and $\mathrm{Q}$ are seen to be controlled when grid frequency and voltage exceed the deadband zones, at these low gain levels the SOC varies by only $5 \%$ over the 2 hour period.

\subsection{Peak load shaving}

Power measurements points are distributed throughout the campus at The University of Manchester. Figure 13 shows daily usage profiles over a 4 week period for a multi-use university building which contains high-power research labs, offices and lecture theatres. The data shows a consistent base load of $190 \mathrm{~kW}$, with a peak demand of approximately $325 \mathrm{~kW}$ appearing only on working days

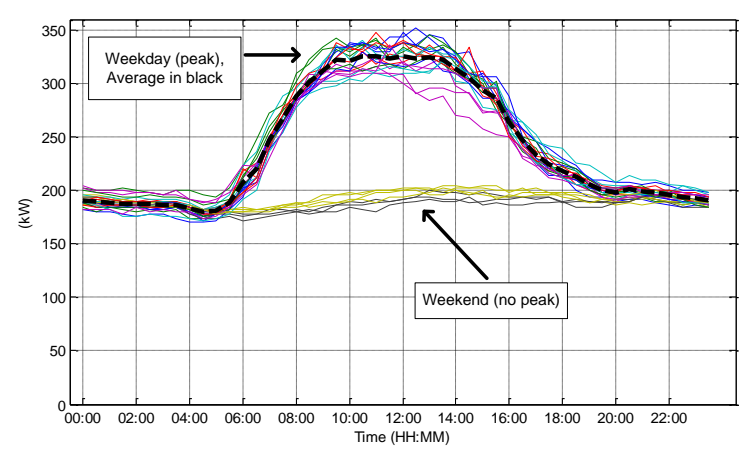

Figure 13: Building daily power demand (06.07 to 02.08.2015)

The consistency of load means that usage can be predicted with some accuracy. The average weekday usage is calculated and processed to create a power profile which is converted to a lookup table for the BESS to follow. This provides a peak shaving capability where the daytime peak load is reduced and the BESS is recharged overnight when the building demand is lowest. Power set points are taken from the lookup table. The BESS power profile and SOC are shown in Figure 14.
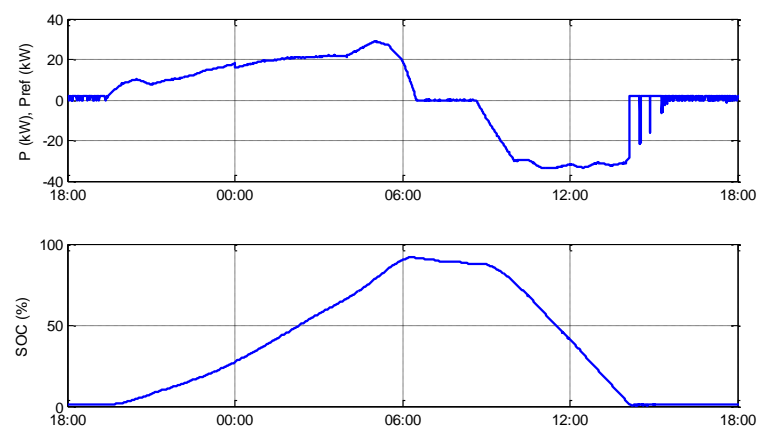

Figure 14: Peak shaving using power profile (28.08.2015)

The battery is charged slowly during the night, with the real power level peaking at $29 \mathrm{~kW}$ when demand is lowest at 05:00. During peak demand, the profile power injects power to reduce peak load by $30 \mathrm{~kW}$. SOC is depleted to $0 \%$ by approximately 14:00, slightly sooner than expected as the profile was designed without consideration of round trip efficiency.

\section{Conclusions}

Two high performance BESSs connected to the UK electricity network are described in this paper. Initial performance results have shown ramp rates as low as $40 \mathrm{~ms}$ for a full $2 \mathrm{MW}$ power reversal, and round trip efficiency of $86.6 \%$ from the 236kVA system. Further results have demonstrated their ability to support the network voltage and frequency and a control scheme is used to automate this showing only a $5 \%$ variation in SOC during a 2 hour period for mild voltage and frequency support. Test data is also provided for the design and implementation of a peak load shifting control scheme functioning on a commercial building. 


\section{Acknowledgements}

The authors are grateful to the UK Engineering and Physical Sciences Research Council for capital investment in 'Advanced Grid-scale Energy Storage R\&D facilities' through the Great Technology Grant.

\section{References}

[1] K. J. Dyke, N. Schofield, and M. Barnes, "The Impact of Transport Electrification on Electrical Networks," IEEE Transactions on Industrial Electronics, vol. 57, no. 12, pp. 3917-3926, 2010.

[2] B. Dunn, H. Kamath, and J.-M. Tarascon, "Electrical Energy Storage for the Grid: A Battery of Choices," Science, vol. 334, no. 6058, pp. 928-935, November 18, 2011.

[3] J. M. Carrasco, L. G. Franquelo, J. T. Bialasiewicz, E. Galvan, R. C. P. Guisado, M. A. M. Prats, J. I. Leon, and N. Moreno-Alfonso, "Power-Electronic Systems for the Grid Integration of Renewable Energy Sources: A Survey," IEEE Transactions on Industrial Electronics, vol. 53, no. 4, pp. 1002-1016, 2006.

[4] S. M. Schoenung, and J. Eyer, Benefit/Cost Framework for Evaluating Modular Energy Storage: A Study for the DOE Energy Storage Systems Program, Sandia National Laboratories, 2008.

[5] K. Bradbury, L. Pratson, and D. Patiño-Echeverri, "Economic viability of energy storage systems based on price arbitrage potential in real-time U.S. electricity markets," Applied Energy, vol. 114, pp. 512-519, February, 2014.

[6] M. Beaudin, H. Zareipour, A. Schellenberglabe, and W. Rosehart, "Energy storage for mitigating the variability of renewable electricity sources: An updated review," Energy for Sustainable Development, vol. 14, no. 4, pp. 302-314, December, 2010.

[7] S. Teleke, M. E. Baran, S. Bhattacharya, and A. Q. Huang, "Rule-Based Control of Battery Energy Storage for Dispatching Intermittent Renewable Sources," IEEE Transactions on Sustainable Energy, vol. 1, no. 3, pp. 117-124, 2010.

[8] J. P. Barton, and D. G. Infield, "Energy storage and its use with intermittent renewable energy," IEEE Transactions on Energy Conversion, vol. 19, no. 2, pp. 441-448, 2004.

[9] J. Gonzalez, and J. Moriarty, "Risk-sensitive optimal switching and applications to district energy systems," in Probabilistic Methods Applied to Power Systems (PMAPS), 2014 International Conference on, Durham, 2014, pp. 1-6.

[10] N. S. Wade, P. C. Taylor, P. D. Lang, and P. R. Jones, "Evaluating the benefits of an electrical energy storage system in a future smart grid," Energy Policy, vol. 38, no. 11, pp. 7180-7188, 11//, 2010.
[11] N. S. Wade, W. Kunpeng, M. Michel, and T. Willis, "Demonstration of a $200 \mathrm{~kW} / 200 \mathrm{kWh}$ energy storage system on an $11 \mathrm{kV}$ UK distribution feeder," in IEEE/PES Innovative Smart Grid Technologies Europe (ISGT EUROPE), Copenhagen, 2013, pp. 1-5.

[12] T. Pultarova, "Massive battery to help balance power supply and demand," Engineering \& Technology, vol. 10, no. 1, pp. 17-17, 2015.

[13] F. Awan, C. Abbey, Y. Brissette, and G. Joos, "Commissioning tests of $100 \mathrm{kWh}$ battery energy storage system for a distribution test line," in 2014 IEEE PES General Meeting, 2014, pp. 1-4.

[14] K. Yoshimoto, T. Nanahara, and G. Koshimizu, "Analysis of data obtained in demonstration test about battery energy storage system to mitigate output fluctuation of wind farm," in Integration of Wide-Scale Renewable Resources Into the Power Delivery System, 2009 CIGRE/IEEE PES Joint Symposium, 2009, pp. 16.

[15] N. Kawakami, Y. Iijima, Y. Sakanaka, M. Fukuhara, K. Ogawa, M. Bando, and T. Matsuda, "Development and field experiences of stabilization system using 34MW NAS batteries for a 51MW wind farm," in IEEE International Symposium on Industrial Electronics (ISIE), 2010, pp. 2371-2376.

[16] A. Joseph, and M. Shahidehpour, "Battery storage systems in electric power systems," in IEEE PES General Meeting, Montreal, 2006, pp. 8 pp.

[17] G. D. Rodriguez, "Operating experience with the Chino $10 \mathrm{MW} / 40 \mathrm{MWh}$ battery energy storage facility," in 24th Intersociety Energy Conversion Engineering Conference (IECEC-89), 1989, pp. 1641-1645 vol.3.

[18] K. C. Divya, and J. Østergaard, "Battery energy storage technology for power systems-An overview," Electric Power Systems Research, vol. 79, no. 4, pp. 511-520, 4//, 2009.

[19] I. Miranda, N. Silva, and H. Leite, "Distribution storage system optimal sizing and techno-economic robustness," in 2012 IEEE International Energy Conference and Exhibition (ENERGYCON), 2012, pp. 483-488.

[20] S. Teleke, M. E. Baran, A. Q. Huang, S. Bhattacharya, and L. Anderson, "Control Strategies for Battery Energy Storage for Wind Farm Dispatching," IEEE Transactions on Energy Conversion, vol. 24, no. 3, pp. 725-732, 2009.

[21] F. Díaz-González, A. Sumper, O. Gomis-Bellmunt, and R. Villafáfila-Robles, "A review of energy storage technologies for wind power applications," Renewable and Sustainable Energy Reviews, vol. 16, no. 4, pp. 2154-2171, May 2012, 2012. 